\title{
Distribution, host range and large-scale spatial variability in black band disease prevalence on the Great Barrier Reef, Australia
}

\author{
Cathie Page* ${ }^{*}$ Bette Willis \\ School of Marine Biology and Aquaculture, James Cook University, Townsville, Queensland 4811, Australia
}

\begin{abstract}
The prevalence and host range of black band disease (BBD) was determined from surveys of 19 reefs within the Great Barrier Reef Marine Park, Australia. Prevalence of BBD was compared among reefs distributed across large-scale cross-shelf and long-shelf gradients of terrestrial or anthropogenic influence. We found that BBD was widespread throughout the Great Barrier Reef (GBR) and was present on $73.7 \%$ of the 19 reefs surveyed in 3 latitudinal sectors and 3 cross-shelf positions in the summer of 2004. Although BBD occurred on all mid-shelf reefs and all but one outershelf reefs, overall prevalence was low, infecting on average $0.09 \%$ of sessile cnidarians and $0.1 \%$ of scleractinian corals surveyed. BBD affected $\sim 7 \%$ of scleractinian taxa $(25$ of approximately $350 \mathrm{GBR}$ hard coral species) and 1 soft coral family, although most cases of BBD were recorded on branching Acropora species. Prevalence of BBD did not correlate with distance from terrestrial influences, being highest on mid-shelf reefs and lowest on inshore reefs (absent from $66 \%, \mathrm{n}=6$, of these reefs). BBD prevalence was consistently higher in all shelf positions in the northern (Cooktown/Lizard Island) sector, which is adjacent to relatively pristine catchments compared to the central (Townsville) sector, which is adjacent to a more developed catchment. BBD cases were clustered within reefs and transects, which was consistent with local dispersal of pathogens via currents, although the spread of BBD was not dependent on the density or cover of any of the coral taxa examined. In combination, these results suggest that BBD is part of the natural ecology of coral assemblages of the GBR, and its prevalence is relatively unaffected by terrestrial influences on the scales characteristic of cross-shelf gradients.
\end{abstract}

KEY WORDS: Black band disease $\cdot$ BBD $\cdot$ Coral disease $\cdot$ Great Barrier Reef $\cdot$ GBR $\cdot$ Cyanobacteria Skeletal eroding band $\cdot$ SEB $\cdot$ Bleaching

\section{INTRODUCTION}

Black band disease (BBD) was first reported from reefs of Belize and the Florida Keys in 1973 (Antonius 1973) but is now known to be widely distributed throughout most reef regions of the world. BBD has been recorded from the Caribbean (Garrett \& Ducklow 1975, Rutzler et al. 1983, Edmunds 1991), the Red Sea (Antonius 1988, Al-Moghrabi 2001), and from IndoPacific locations including Fiji (Littler \& Littler 1996), the Philippines (Antonius 1985b), Papua New Guinea (Frias-Lopez et al. 2003) and the Great Barrier Reef (GBR) (Miller 1996, Dinsdale 2000, Willis et al. 2004).
Although generally low in prevalence $(<5 \%$ of all corals) in most reef regions (Edmunds 1991, Bruckner et al. 1997, Dinsdale 2000, Weil et al. 2002), BBD infections have been found to persist on the same reef for years and possibly for decades in the Caribbean, contributing to the long-term mortality of susceptible coral species (Bruckner \& Bruckner 1997). Low level chronic infections of BBD over years to decades are predicted to reduce the size of coral populations (Edmunds 1991) and consequently their reproductive output and recruitment, while differential susceptibility of species to BBD may result in long-term changes to coral community structure (Bruckner \& Bruckner 1997). 
Despite the potential chronic impact of BBD on reef corals worldwide, most research on this disease has focussed on reefs within the wider Caribbean region (Edmunds 1991, Bruckner \& Bruckner 1997, Porter et al. 2001, Weil et al. 2002). On Indo-Pacific reefs, BBD was first recorded on massive faviid species in the Philippines and the Red Sea between 1981 and 1984 (Antonius 1985b). It was almost another decade before BBD was recorded on reefs of the GBR (Miller 1996), despite its probable presence prior to this. Miller (1996) recorded BBD on $19 \%$ of 110 reefs surveyed over a 3 yr period (1993 to 1996) and concluded that BBD 'exists at low levels' throughout the GBR, with cases restricted to the families Acroporidae and Poritidae. The first quantitative study of BBD prevalence on the GBR expanded the number of susceptible taxa to 21 species in 5 scleractinian families (Acroporidae, Pocilloporidae, Faviidae, Poritidae and Mussidae) and found BBD affected 1.3 to $4.9 \%$ of all corals at Lizard Island (Dinsdale 2000). More recently, BBD and other cyanobacterial infections were recorded on 28 species from 8 scleractinian families on 3 GBR reefs selected because of high disease abundance in general. However, the low prevalence of BBD and other cyanobacterial infections ( 0.01 to $1.5 \%$ of all corals) in this study and the very low frequency of BBD cases recorded throughout the previous $5 \mathrm{yr}$ period (1998 to 2003) (Willis et al. 2004) suggest that BBD prevalence has remained low on the GBR since at least 1994. BBD levels on the $3 \mathrm{GBR}$ reefs where prevalence has been quantified (Willis et al. 2004) are comparable to prevalence on many reefs in the Caribbean (Edmunds 1991, Kuta \& Richardson 1996, Bruckner \& Bruckner 1997), but studies over larger spatial scales are required to determine how indicative these reefs are of the GBR in general and to determine the distribution and host range of BBD throughout the GBR.

Environmental conditions experienced by corals are thought to be important in determining the occurrence and prevalence of BBD (Antonius 1981, 1985, Littler \& Littler 1996, Bruckner et al. 1997, Al-Moghrabi 2001, Frias-Lopez et al. 2002, Kuta \& Richardson 2002), although only one study has quantitatively examined links between environmental parameters and BBD (Kuta \& Richardson 2002). Florida Keys patch reefs with BBD-infected corals present were shallower in the water, experienced higher water temperatures, higher nitrite concentrations, lower orthophosphate concentrations and had lower coral diversity than reefs with no BBD infections (Kuta \& Richardson 2002). Environmental gradients among GBR reefs associated with (1) distance across the continental shelf (cross-shelf gradients), and (2) distance from developed catchments (long-shelf or latitudinal gradients) provide a unique tool for identifying factors correlated with the preva- lence of BBD in the Indo-Pacific. Cross-shelf gradients between inner- and outer-shelf reefs on the GBR include decreasing exposure to terrestrial influences such as nutrients, suspended particulate matter (including sediments) and pollutants (Furnas et al. 1990, Furnas 2003) coupled with increasing wave exposure (Done 1982). On mid- and outer-shelf reefs of the GBR, the concentrations of suspended matter are typically less than $1 \mathrm{mg} \mathrm{l^{-1 }}$, while concentrations on inner-shelf reefs span a much larger range from $<1$ to $>200 \mathrm{mg} \mathrm{l}^{-1}$ (Furnas 2003). Higher levels of suspended matter on inner-shelf reefs result in a reduction in water transparency and light levels for corals growing on these reefs and sediment smothering in extreme cases (Wolanski et al. 2003). Dissolved and particulate nutrients, especially particulate nitrogen, are also typically higher in inshore waters of the GBR and decrease across the continental shelf (Furnas 2003). Long-shelf gradients between the northern (Cooktown/Lizard Island) and central (Townsville) sectors relate to land use patterns and development levels in adjacent catchments. In particular, catchments adjacent to the Townsville sector are characterised by urban development and heavy land clearing for sugar cane farming and cattle grazing, whereas catchments adjacent to the Lizard Island sector are comparatively pristine (Furnas et al. 1990, Furnas 2003). Within the main river catchments adjacent to the northern Cooktown/Lizard Island sector, between 1 and $7 \%$ of land is cleared compared to $17-30 \%$ of the main river catchments adjacent to the central Townsville sector (Furnas 2003). High levels of clearing in the Townsville sector may contribute to higher output of terrigenous sediment by river systems in adjacent catchments (Furnas 2003). Reefs in the southern (Heron Island) sector are more than $80 \mathrm{~km}$ from the coast and relatively free from coastal terrigenous inputs. Consequently, crossshelf studies of coral disease in these 3 sectors of the GBR provide a unique opportunity to examine the influence of environmental parameters related to terrestrial inputs on the prevalence of BBD.

In this study, we quantify the prevalence of BBD on 19 reefs of the GBR located in 3 latitudinal sectors and spread over 3 cross-shelf positions that represent a gradient of terrestrial influence with respect to nutrients, suspended sediment and other pollutants. This is the first study of coral disease prevalence on the GBR that encompasses both large-scale cross-shelf and long-shelf gradients. The aims of this study were to: (1) compare variability in BBD prevalence between latitudinal sectors and cross-shelf positions, (2) identify all taxa susceptible to BBD on the GBR, and (3) examine coral community attributes and environmental factors influencing BBD prevalence across a gradient of terrestrial influence. 


\section{MATERIALS AND METHODS}

To examine spatial variability in the prevalence of BBD between reefs adjacent to comparatively pristine versus developed catchments and to determine the taxa affected by BBD on the GBR, disease prevalence was surveyed within 3 latitudinal sectors in January to March 2004 according to methods described in Willis et al. (2004). According to Willis et al. (2004), BBD and other cyanobacterial infection prevalence was significantly higher during summer compared to winter surveys in one year at Lizard Island, consistent with BBD prevalence varying seasonally on the GBR. Therefore, to maximise documentation of host ranges and terrestrial impacts on prevalence of BBD on the GBR, reefs were surveyed during summer when the BBD prevalence is likely to be highest (Willis et al. 2004).

To examine spatial variability in the prevalence of BBD along gradients of terrestrial influences, 3 haphazardly selected reefs were surveyed within each of 3 cross-shelf positions (inner-, mid- and outer-shelf) in 2 latitudinal sectors (Cooktown/Lizard Island and Townsville, henceforth referred to respectively as the northern and central sectors) (Fig. 1). The cross-shelf transects represent a gradient of decreasing terrestrial influence and increasing wave exposure from the inner to outer-shelf positions. On each reef, 2 sites were haphazardly selected within the north-west sheltered back reef zone. One sheltered and one exposed site at one reef (Heron Island) in the southern-most Capricorn Bunker group (henceforth referred to as the southern sector) was surveyed to examine how BBD prevalence varied between northern and southern sectors of the GBR. Mid- or inner-shelf reefs were not surveyed in the southern sector due to a paucity of coral reefs in these cross-shelf positions in this latitudinal sector (Cheal et al. 2001). Reefs surveyed in each latitudinal sector are shown in Fig. 1 and listed in Table 1.

At each site, we haphazardly placed three $20 \times 2 \mathrm{~m}$ belt transects parallel to depth contours on the reef slope at 3 to $6 \mathrm{~m}$ depth. Within each $20 \times 2 \mathrm{~m}$ belt, all scleractinians, gorgonians, alcyonaceans and hydrocorals were examined for signs of BBD. The presence or absence of BBD on each colony was recorded and corals were identified to the lowest taxonomic or morphological group, as appropriate. All other signs of disease on colonies with BBD were also recorded. To further extend records of host range on the GBR, all

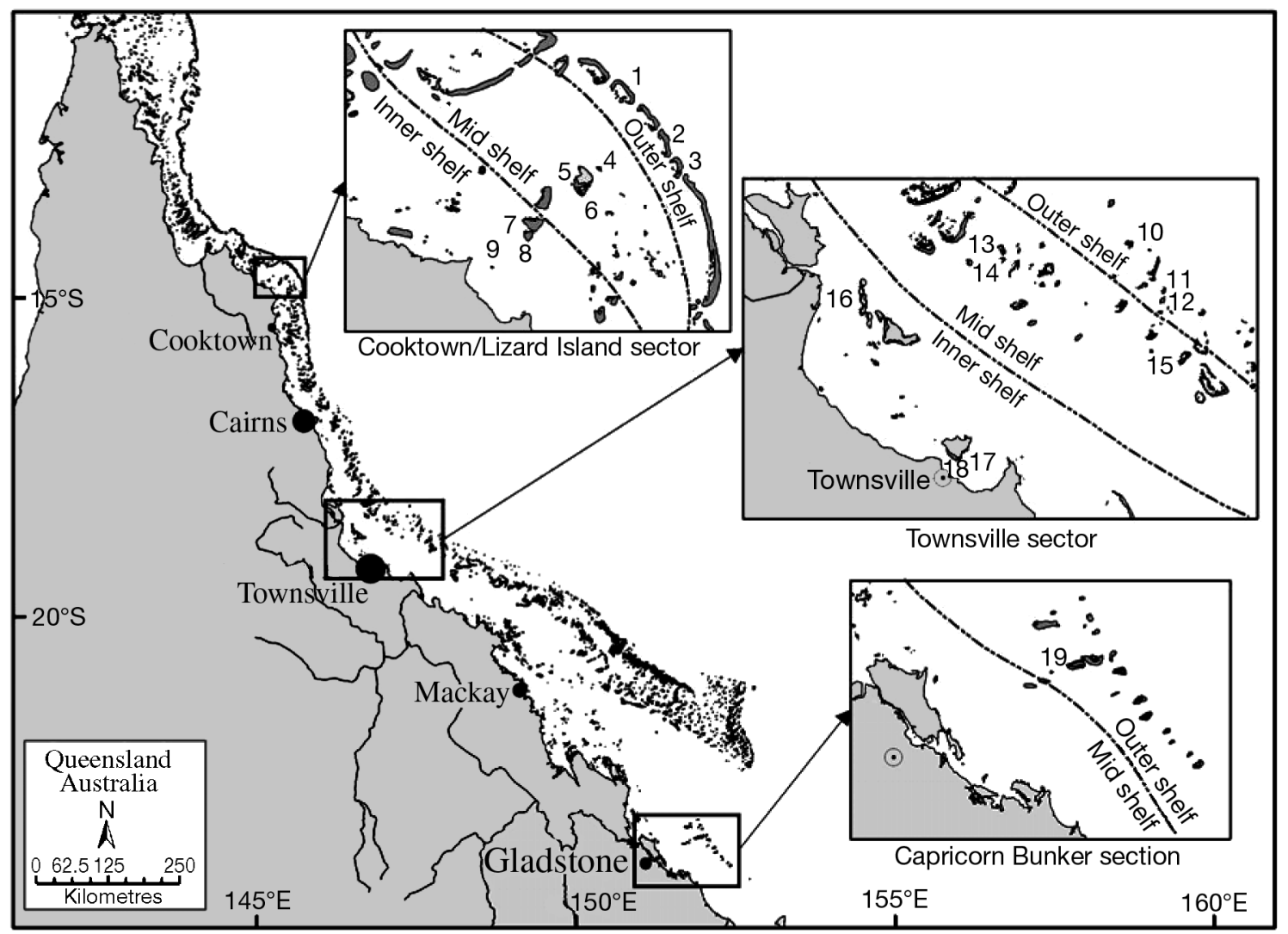

Fig. 1. Reefs surveyed for black band disease (BBD) in 3 latitudinal sectors of the Great Barrier Reef. Reefs numbered as follows: (1) Day Reef, (2) Yonge Reef, (3) No Name Reef, (4) Macgillivray Reef, (5) Lizard Island, (6) North Direction Island, (7) Martin Reef, (8) Linnet Reef, (9) Maxwell Reef, (10) Dip Reef, (11) Knife Reef, (12) Fork Reef, (13) Kelso Reef, (14) Little Kelso Reef, (15) Davies Reef, (16) Orpheus Island, (17) Magnetic Island, (18) Middle Reef, (19) Heron Island 
Table 1. Total number of black band disease (BBD) cases and BBD prevalence per reef

\begin{tabular}{|c|c|c|c|c|}
\hline $\begin{array}{l}\text { Latitudinal } \\
\text { sector }\end{array}$ & $\begin{array}{l}\text { Cross-shelf } \\
\text { position }\end{array}$ & Reef name & $\begin{array}{l}\text { Number of } \\
\text { BBD cases }\end{array}$ & $\begin{array}{c}\text { BBD pre- } \\
\text { valence (\%) }\end{array}$ \\
\hline \multirow{9}{*}{$\begin{array}{l}\text { Cooktown / } \\
\text { Lizard Island } \\
\text { (northern) }\end{array}$} & \multirow[t]{3}{*}{ Inner- } & Linnet Reef & 4 & 0.061 \\
\hline & & Martin Reef & 2 & 0.020 \\
\hline & & Maxwell Reef & 0 & 0.000 \\
\hline & \multirow[t]{3}{*}{ Mid- } & Lizard Island & 1 & 0.013 \\
\hline & & Macgillivray Reef & 6 & 0.101 \\
\hline & & North Direction Island & 48 & 0.696 \\
\hline & \multirow[t]{3}{*}{ Outer } & Day Reef & 18 & 0.261 \\
\hline & & No Name Reef & 0 & 0.000 \\
\hline & & Yonge Reef & 3 & 0.047 \\
\hline \multirow{9}{*}{$\begin{array}{l}\text { Townsville } \\
\text { (central) }\end{array}$} & \multirow[t]{3}{*}{ Inner- } & Magnetic Island & 0 & 0.000 \\
\hline & & Middle Reef & 0 & 0.000 \\
\hline & & Orpheus Island & 0 & 0.000 \\
\hline & \multirow[t]{3}{*}{ Mid- } & Davies Reef & 4 & 0.132 \\
\hline & & Kelso Reef & 6 & 0.104 \\
\hline & & Little Kelso Reef & 3 & 0.083 \\
\hline & \multirow[t]{3}{*}{ Outer- } & Dip Reef & 3 & 0.063 \\
\hline & & Fork Reef & 2 & 0.037 \\
\hline & & Knife Reef & 3 & 0.063 \\
\hline \multirow{2}{*}{$\begin{array}{l}\text { Capricorn } \\
\text { Bunkers (southern) }\end{array}$} & Outer- & Heron Island & 1 & 0.012 \\
\hline & & & & \\
\hline
\end{tabular}

corals with signs of BBD observed outside of the belttransects were identified to the lowest taxonomic or morphological group as appropriate and noted separately.

The effects of latitude, cross-shelf position and their interaction were tested using the linear model: BBD = latitude + cross-shelf position + latitude $\times$ cross-shelf position. The response variable was the binary classification of coral colonies as either diseased or nondiseased. Binary data are not modelled well by classical analysis of variance because random errors of binary data are unlikely to be normally distributed. Consequently, we chose a categorical data analysis of the linear model using a logistic regression in which the independent factors were defined as classes rather than continuous variables and the logit (the log of the ratio of probability of disease versus non-diseased) was the link function (McCullagh \& Nelder 1989). We first fitted a main effects-only model and secondly the saturated model, and evaluated their relative goodness of fit using Schwarz's Bayesian Criterion. This sequential approach was required to avoid over-fitting the model.

To determine whether cases of BBD were aggregated or randomly distributed, the frequency distributions of cases of BBD per transect and reef were tested for goodness of fit to a Poisson distribution using chisquared tests.

Coral cover was determined at each site from line intercept data recorded along the central line of each belt transect. The relationships between BBD prevalence and both the cover and density of all corals, scleractinian corals and acroporid corals were examined using regressions. A G-test was used to determine if all families found to have BBD infections were equally susceptible. All families without BBD infections were excluded and data from all reefs were pooled to satisfy test requirements that cells contain a minimum frequency of 5 .

Cyanobacterial infections exhibiting gross morphological differences to $\mathrm{BBD}$ (i.e. not forming a blackish matt or band) were recorded separately from BBD and are discussed only briefly in this paper. Cyanobacteria that appear to be morphologically distinct from the cyanobacteria dominant in BBD mats have been recorded previously from the GBR, but their status is still unresolved (Willis et al. 2004).

\section{RESULTS}

\section{Distribution and spatial variability of BBD}

The distribution of BBD on the GBR was widespread in the summer (January-March) of 2004, being recorded from $73.7 \%$ of the 19 reefs surveyed across sectors in each of the northern, central and southern sections of the Great Barrier Reef Marine Park. The proportions of reefs with BBD in the northern $(88.9 \%)$ and central (66.7\%) sectors were high and not statistically distinguishable (Yates corrected $\chi^{2}=0.32$, $\mathrm{df}=1$, $\mathrm{p}=0.57$ ). BBD was also present on the 1 reef surveyed in the southern sector. BBD was recorded on all midshelf reefs in both the northern and central sectors and on all outer-shelf reefs in each of the 3 sectors, with the exception of 1 outer-shelf reef in the northern sector. In contrast, BBD was absent from all inner-shelf reefs in the central sector and 1 inner-shelf reef (Maxwell Reef) in the northern sector.

Although BBD was recorded from $73.7 \%$ of reefs and $70.2 \%$ of transects, the distribution of BBD cases was not random. Cases of BBD were clumped at both the reef $\left(\chi^{2}=282.3, \mathrm{df}=3, \mathrm{p}<0.001\right)$ and transect level $\left(\chi^{2}=\right.$ 589.5 , df $=3, \mathrm{p}<0.001)$. Despite its clumped distribution, the prevalence of BBD was not dependent on the density or cover of any coral taxa examined. We found no significant relationship between BBD prevalence and either cover $\left(\mathrm{r}^{2}=0.009, F=0.146, \mathrm{p}=0.7\right)$ or density $\left(\mathrm{r}^{2}=0.08, F=0.126, \mathrm{p}=0.72\right)$ when all corals (scleractin- 
ian, octocoral and hydrocorals) were combined. Since most cases of BBD were recorded from scleractinian corals and specifically from corals within the family Acroporidae, the analyses were repeated, excluding first all non-scleractinian corals and then non-acroporid corals. However, there was still no significant relationship between BBD prevalence and cover $\left(\mathrm{r}^{2}=0.028, F=\right.$ $0.465, \mathrm{p}=0.5)$ or density $\left(\mathrm{r}^{2}=0.016, F=0.254, \mathrm{p}=0.62\right)$ of scleractinian corals, nor between BBD prevalence and cover $\left(\mathrm{r}^{2}=0.095, F=1.67, \mathrm{p}>0.21\right)$ or density $\left(\mathrm{r}^{2}=\right.$ $0.1, F=1.66, p=0.217$ ) of acroporid corals (Fig. 2).
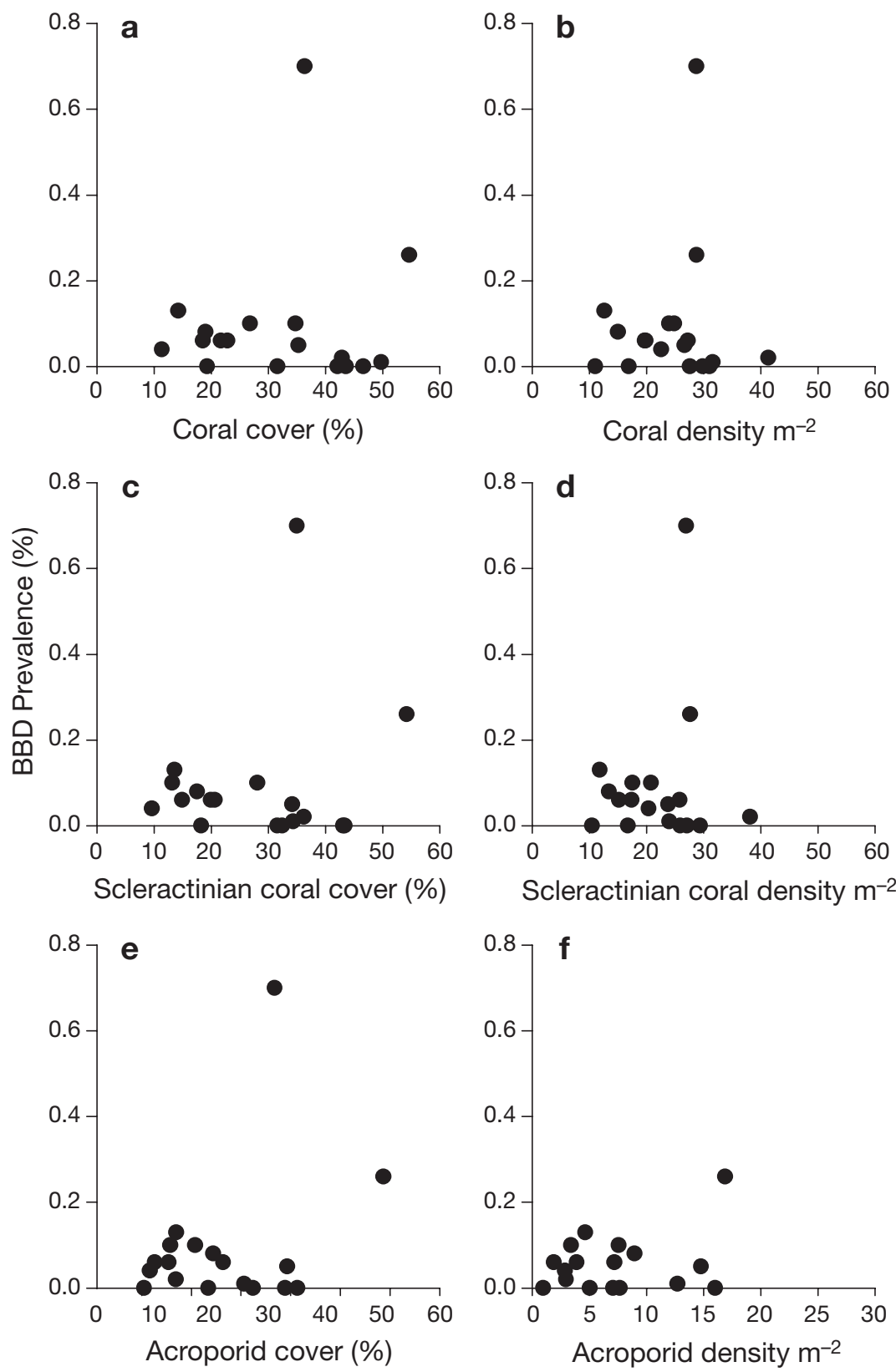

Fig. 2. Relationship between BBD prevalence and (a) cover of all corals, (b) density of all corals, (c) cover of scleractinian corals, (d) density of scleractinian corals, (e) cover of acroporid corals, (f) density of acroporid corals
The prevalence of BBD on the GBR was low, affecting on average $0.09 \% \pm 0.04$ of corals per reef $(n=19$ reefs) (Table 1). In the northern and central sectors, only 103 colonies of the 105421 examined were infected. The highest prevalence was recorded at North Direction Island in the northern sector, where $0.7 \%$ $(n=6899)$ of corals were infected. Only 1 case of BBD was recorded from the 2 sites surveyed in the southern sector (i.e. $0.012 \%$ of 8326 corals surveyed). On the GBR, BBD predominately affects scleractinian corals, with only 1 recorded case for soft corals. If all non-scleractinian corals are excluded, BBD prevalence increases slightly to an average of $0.1 \%$ of all scleractinian corals, with prevalence ranging between 0 and $0.74 \%$ of scleractinian corals per reef.

The prevalence of BBD was consistently higher in the northern sector in comparison to the central sector at all cross-shelf positions (Table 2, Fig. 3). Cross-shelf patterns in BBD prevalence were consistent in both the northern and central sectors, with the percentage of infected corals peaking on mid-shelf reefs and reaching minima on inner-shelf reefs. In fact, no cases of BBD were recorded from innershelf reefs in the central sector (Tables 1 \& 2, Fig. 3). Although there are clear cross-shelf differences in BBD prevalence in the central sector, this pattern is not as robust in the northern sector, due to the higher variation in BBD prevalence at mid- and outer-shelf reefs. This was because, although reefs were selected haphazardly, one reef in each of the midand outer-shelf positions in the northern sector is largely driving cross-shelf and long-shelf patterns in BBD prevalence in this sector $(87 \%$ of BBD cases recorded from the northern sector mid-shelf and $86 \%$ of cases from the northern sector outer-shelf were each recorded from single reefs, i.e. North Direction Island and Day Reef respectively). However, the overall similarity in the cross-shelf pattern found in the central sector supports the generality of this pattern.

\section{Host range}

BBD predominately affects scleractinian corals on the GBR, with only one case of BBD affecting a soft coral recorded from the 19 reefs surveyed. In total, cases 
Table 2. Linear regression analyses of proportion of corals affected by BBD

\begin{tabular}{|c|c|c|c|c|c|c|}
\hline \multirow[t]{2}{*}{ Factor } & \multicolumn{3}{|c|}{ Model 1} & \multicolumn{3}{|c|}{$\begin{array}{c}\text { Model } 2 \\
\text { (Saturated model) }\end{array}$} \\
\hline & $\mathrm{df}$ & $\chi^{2}$ & $\mathrm{p}$ & $\mathrm{df}$ & $\chi^{2}$ & $\mathrm{p}$ \\
\hline Sector & 1 & 14.6809 & 0.0001 & 1 & 0.0013 & 0.9716 \\
\hline Shelf & 2 & 43.5908 & $<0.0001$ & 1 & 10.1871 & 0.0061 \\
\hline Sector $\times$ Shelf & & & & 1 & 0.3535 & 0.8380 \\
\hline $\begin{array}{r}\Delta \text { in Schwarz's } \\
\text { Bayesian crite }\end{array}$ & erior & \multicolumn{2}{|c|}{79.97} & \multicolumn{3}{|c|}{$-0.722^{\mathrm{a}}$} \\
\hline
\end{tabular}

of BBD were recorded from 7 scleractinian families (Acroporidae, Pocilloporidae, Poritidae, Faviidae, Mussidae, Siderastreidae and Dendrophylliidae), 12 scleractinian genera and at least 25 species ( 7\% of GBR scleractinian corals) (Table 3 ). In many cases the species affected could not be identified in the field and so were recorded only to genus and morphological group. Therefore, Table 3 represents an underestimate of the number of species affected by BBD on the GBR. These records include 8 new species or taxa, extending

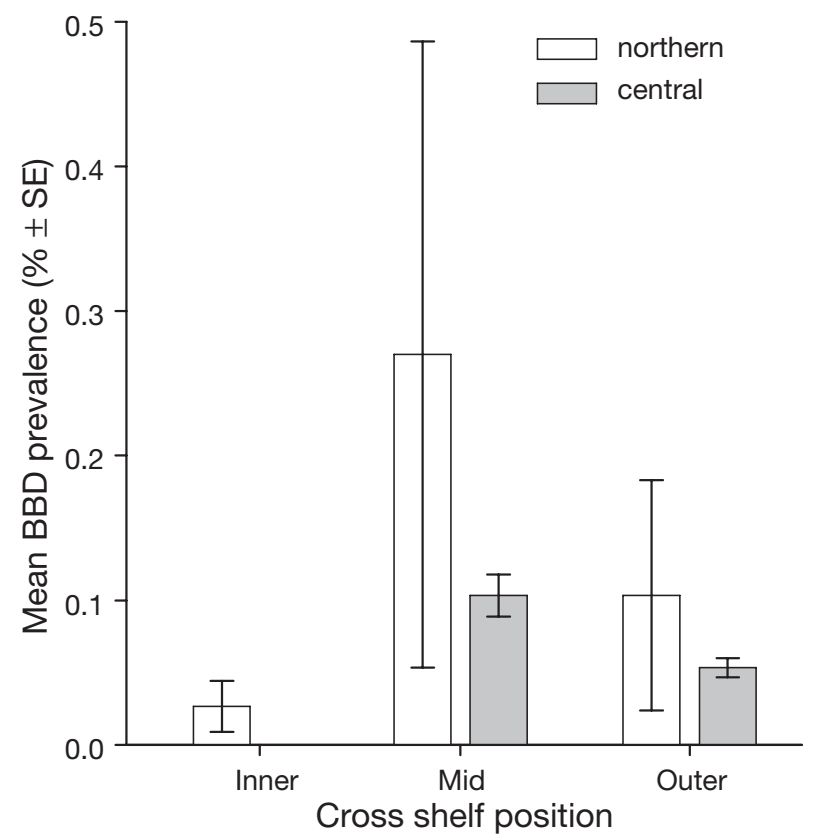

Fig. 3. Percentage of all corals affected by BBD in each cross shelf position in the northern (Cooktown/Lizard Island) and central (Townsville) sectors of the Great Barrier Reef in the summer of 2004

Table 3. Total number of cases of BBD and occurrence of BBD in combination with other disease signs, for all taxa

\begin{tabular}{|c|c|c|c|c|c|c|c|}
\hline Family & Genus & $\begin{array}{l}\text { Morphological group } \\
\text { and/or species }\end{array}$ & Total & $\mathrm{BBD}$ & $\begin{array}{l}\text { BBD and } \\
\text { bleaching }\end{array}$ & $\begin{array}{l}\text { BBD and } \\
\text { SEB }\end{array}$ & $\begin{array}{l}\text { BBD and SEB } \\
\text { and bleaching }\end{array}$ \\
\hline \multirow[t]{9}{*}{ Acroporidae } & \multirow[t]{6}{*}{ Acropora } & $\begin{array}{l}\text { Staghorn Acropora spp. } \\
\text { (A. muricata, A. florida, } \\
\text { A. intermedia) }\end{array}$ & $76,3^{\mathrm{a}}$ & $65,3^{\mathrm{a}}$ & 4 & 4 & 3 \\
\hline & & $\begin{array}{l}\text { Tabulate Acropora spp. } \\
\text { (A. cytherea, A. hyacinthus) }\end{array}$ & $7,2^{\mathrm{a}}$ & $7,2^{\mathrm{a}}$ & 0 & 0 & 0 \\
\hline & & Bushy Acropora spp. & 3 & 3 & 0 & 0 & 0 \\
\hline & & Corymbose Acropora spp. & 2 & 2 & 0 & 0 & 0 \\
\hline & & Digitate Acropora spp. & $1,1^{\mathrm{a}}$ & $1,1^{\mathrm{a}}$ & 0 & 0 & 0 \\
\hline & & Bottlebrush Acropora spp. & 1 & 1 & 0 & 0 & 0 \\
\hline & (Sub-genus Isopora) & A. bruggemanni & 1 & 1 & 0 & 1 & 0 \\
\hline & Astreopora & Astreopora sp. & 1 & 1 & 0 & 0 & 0 \\
\hline & Montipora & Montipora spp. & $2,3^{\mathrm{a}}$ & $2,3^{\mathrm{a}}$ & 0 & 0 & 0 \\
\hline \multirow[t]{4}{*}{ Pocilloporidae } & \multirow{2}{*}{ Pocillopora $^{\mathrm{a}}$} & P. damicornis ${ }^{\mathrm{a}}$ & $2^{\mathrm{a}}$ & $2^{\mathrm{a}}$ & 0 & 0 & 0 \\
\hline & & Other Pocillopora $^{\mathrm{a}}$ & 3 & 3 & 0 & 0 & 0 \\
\hline & Seriatopora & Seriatopora hystrix & $2,1^{\mathrm{a}}$ & $2,1^{\mathrm{a}}$ & 0 & 0 & 0 \\
\hline & Stylophora & Stylophora pistillata & $1,1^{\mathrm{a}}$ & $1,1^{\mathrm{a}}$ & 0 & 0 & 0 \\
\hline \multirow[t]{4}{*}{ Poritidae } & \multirow[t]{3}{*}{ Porites } & Branching Porites spp. & 2 & 2 & 0 & 0 & 0 \\
\hline & & Massive Porites spp. & 2 & 2 & 0 & 0 & 0 \\
\hline & & Other Porites sp. & 1 & 1 & 0 & 0 & 0 \\
\hline & \multirow[t]{2}{*}{ Goniopora $^{\mathrm{a}}$} & Goniopora sp. ${ }^{\mathrm{a}}$ & $1^{\mathrm{a}}$ & $1^{\mathrm{a}}$ & 0 & 0 & 0 \\
\hline Mussidae $^{a}$ & & & 1 & 1 & 0 & 0 & 0 \\
\hline \multirow[t]{2}{*}{ Faviidae $^{a}$} & Favia $^{\mathrm{a}}$ & Favia sp. ${ }^{\mathrm{a}}$ & $1^{\mathrm{a}}$ & $1^{\mathrm{a}}$ & 0 & 0 & 0 \\
\hline & Cyphastrea ${ }^{\mathrm{a}}$ & Cyphastrea sp. ${ }^{\mathrm{a}}$ & $1^{\mathrm{a}}$ & $1^{\mathrm{a}}$ & 0 & 0 & 0 \\
\hline Sideraestreidae ${ }^{\mathrm{a}}$ & Psammacora $^{\mathrm{a}}$ & Psammacora minuta $^{\mathrm{a}}$ & $1^{\mathrm{a}}$ & $1^{\mathrm{a}}$ & 0 & 0 & 0 \\
\hline Dendrophyllidae & Turbinaria & Turbinaria sp. & 1 & 1 & 0 & 0 & 0 \\
\hline Alcyoniidae & & & 1 & 1 & 0 & 0 & 0 \\
\hline
\end{tabular}


the number of hosts for BBD on the GBR from 32 (Willis et al. 2004) to 40. Based on the belt-transect surveys on sheltered sites at 19 reefs, the 7 families affected by BBD were found to differ in their susceptibilities to infection ( $G$-test $=126.808, \mathrm{df}=3, \mathrm{p}<0.01$ ). Species within the family Acroporidae were by far the most susceptible, with $90 \%$ of all infections found on species within this family. All genera within the family Acroporidae (including the sub-genus Isopora) were affected; however branching species of Acropora (particularly A. muricata, A. florida and A. intermedia) were the most often affected species. Five percent of BBD infections were recorded from species in the family Poritidae, $3 \%$ from the family Pocilloporidae and $1 \%$ of infections from each of the families Dendrophylliidae and Alcyoniidae.

\section{BBD in combination with other disease signs and other cyanobacterial infections}

Approximately $10 \%$ of colonies with signs of BBD also showed signs of either bleaching (3.4\%), skeletal eroding band (SEB) (4.3\%), or signs of both of these disease states combined (2.6\%). Fig. 4 shows a colony of Acropora muricata infected with both BBD and the heterotrich folliculinid Halofolliculina corallasia, the putative causative agent of SEB (Antonius \& Lipscomb 2001). In the specimen pictured, the $H$. corallasia indi-

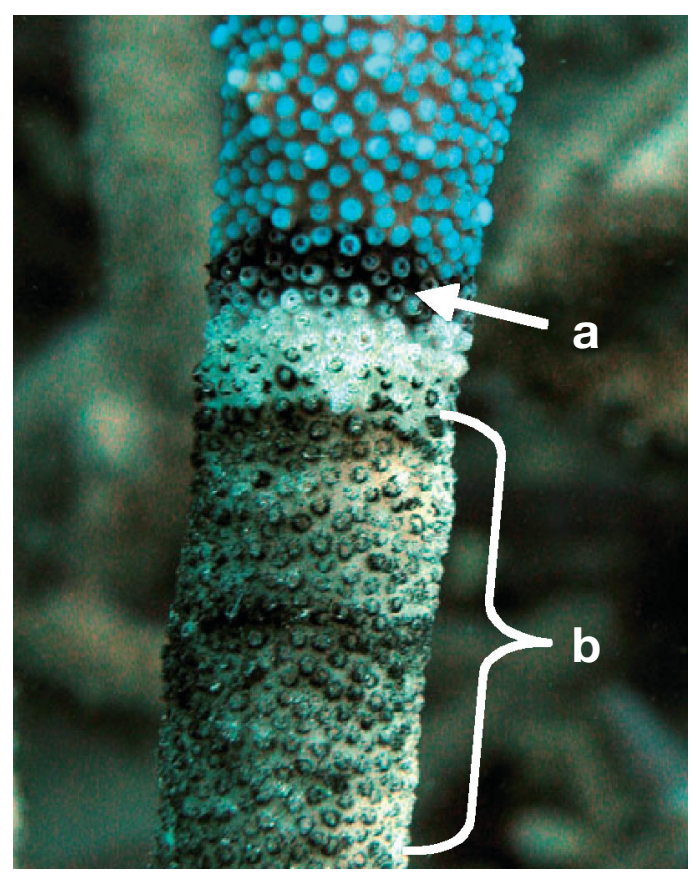

Fig. 4. (a) The characteristic black cyanobacteria mat of BBD and (b) Halofolliculina corallasia (the putative causative agent of skeletal eroding band, SEB) on the same colony of Acropora muricata viduals are embedded in the coral skeleton behind the BBD front, suggesting that the cyanobacterial mat is the main cause of coral mortality. In some cases, however, groups of $H$. corallasia have been observed both ahead of the BBD front and amongst the BBD cyanobacterial mat. Eleven of the 12 cases of BBD occurring with other signs of disease were recorded on branching Acropora species.

\section{DISCUSSION}

The detection of BBD on $74 \%$ of reefs surveyed $(\mathrm{n}=$ 19) and in 3 latitudinal sectors, encompassing $1000 \mathrm{~km}$ of the Queensland coast, indicates that BBD is widely distributed over the length of the Great Barrier Reef. This contrasts with findings of other authors: Miller (1996) found that BBD was present on only $19 \%$ of 110 GBR reefs surveyed between 1993 and 1996, while the Australian Institute of Marine Science Long-term Monitoring Program (AIMS LTMP; unpubl. data) found BBD was present on between 2 and $17 \%$ of 48 GBR reefs between 1998 and 2004. These differences in findings are almost certainly attributable to differences in survey methods, the timing of surveys and differences in the reef zone surveyed. The up to 4 -fold greater percentage of reefs with BBD in our study reflects the greater likelihood of detecting macroscopic signs of the disease by searching a comparatively small belt transect by SCUBA. The Manta Tow and opportunistic surveys of large $\left(>750 \mathrm{~m}^{2}\right)$ areas used by Miller (1996) involve observers scanning large areas of reef in a relatively short period of time and generally from a distance well above the substratum, while the AIMS LTMP surveys involve a single observer using SCUBA scanning a $1500 \mathrm{~m}^{2}$ area rapidly (typically in less than $1.5 \mathrm{~h}$ ), all of which mitigate against accurate observations of BBD presence. Although it is possible that the distribution of BBD has spread to encompass more reefs in recent years, the greater accuracy of belt transects using SCUBA to closely examine each coral is a more likely explanation of the wider distribution of BBD detected in our surveys. Our surveys were conducted on sheltered northwest back reef sites in 3 to $6 \mathrm{~m}$, whereas surveys of belt transects by the AIMS LTMP SCUBA are located on the exposed northeast flank in 6 to $9 \mathrm{~m}$ of depth (Sweatman et al. 2001). Given that BBD is commonly restricted to shallow $(<6 \mathrm{~m})$ reef environments (Kuta \& Richardson 2002), and was more prevalent at sheltered sites than at exposed sites at the northern sector (Willis et al. 2004) it is not surprising that our surveys revealed a higher distribution of BBD than surveys by the AIMS LTMP in a deeper more exposed habitat. 
An additional factor contributing to the higher percentage of reefs with BBD in this study is the timing of surveys. Temperature is thought to be an important factor influencing the prevalence and spread of BBD, with higher prevalence recorded in summer from reefs in both the Caribbean (Rutzler et al. 1983, Edmunds 1991) and the GBR (Willis et al. 2004). Miller's (1996) surveys and the AIMS LTMP surveys (Sweatman et al. 2001) were spread across both winter and summer months, whereas our surveys were timed for the summer months when average seawater temperatures are highest, which is likely to have contributed to the greater number of reefs with active BBD infections. Differences in the distribution of BBD on the GBR found by our study and Miller (1996) highlight the importance of developing standardized survey methods that can be used on a global scale to both allow direct comparisons of coral disease data collected in different geographical regions, and to increase the likelihood of detection of changes in the distribution and prevalence of coral diseases at a variety of spatial scales. At present circular or arc transects (Santavy et al. 2001) and belt transects are used to measure coral disease prevalence in the Caribbean (Porter 2001, Patterson et al. 2004, Weil 2004), while belt transects are used in the Indo-Pacific (Willis et al. 2004). Given the range of depths the circular or arc method may encompass on some steeply sloping reef communities of the Indo-Pacific, we suggest that the belt transect method, described in this and other recent studies of coral disease in the Indo-Pacific (Raymundo et al. 2003, 2005, Willis et al. 2004) is the more appropriate method for use in coral disease surveys worldwide to enable geographical comparisons of coral disease data. However, a quantitative comparison of coral disease survey methods used globally would be timely.

While widespread on the GBR, BBD was absent from $80 \%$ of inshore reefs surveyed, which are the reefs that typically experience the highest levels of nutrients, sediment and pollutants from adjacent mainland catchments (Furnas 2003). The reasons for its absence on these reefs are unclear, particularly given correlations found between the occurrence or activity of BBD and both elevated nutrients (Kuta \& Richardson 2002) and poor water quality (Antonius 1988, Al-Moghrabi 2001) in other reef regions. Other studies have supported a link between poor water quality and high BBD prevalence (Taylor 1983, Bruckner et al. 1997), although only one found a quantitative correlation between BBD occurrence and water quality parameters (including higher than average water temperatures, nitrite and orthophosphate concentrations; Kuta \& Richardson 2002). Levels of terrestrial inputs experienced by reefs of the GBR not only vary across the shelf, but also between the northern and central sec- tors of the GBR as a consequence of land-use practices, rainfall and other characteristics of adjacent catchments (Furnas 1990, 2003). Here again, the higher prevalence of $\mathrm{BBD}$ in the relatively more pristine northern sector compared to the central sector (Fig. 3) is contrary to the pattern that would be predicted based on previous studies of BBD. Patterns of highest BBD prevalence on mid-shelf reefs in the northern sector provide further evidence that terrestrial inputs from mainland catchments may not be the primary factors determining the prevalence of BBD on the GBR. However, overall levels of nutrients on reefs of the GBR may be below thresholds that may drive BBD outbreaks on Caribbean reefs. Given the increasing evidence of a link between eutrophication of coral reef waters and increases in coral disease prevalence and activity worldwide (Bruno et al. 2003, Harvell et al. 2004), a study of the relationship between BBD and a wide range of nutrients, would shed further light on potential links between BBD and terrestrial inputs on the GBR.

Differences in coral community structure between inner-, mid- and outer-shelf reefs were also tested as a potential explanation for the lack of BBD on inner-shelf reefs. Given that the greatest number of cases of BBD were recorded from species in the genus Acropora (Table 3) and in particular branching species (Acropora muricata, A. intermedia and A. florida), it is tempting to invoke the low abundance of acroporid corals that has been found on many inner-shelf reefs in past studies of the GBR (Done 1982, Ninio \& Meekan 2002) as an explanation for BBD absence on these reefs. However, in contrast to these previous surveys, we found a high (45 to $95 \%$ of taxa) abundance of acroporid corals on inshore reefs on which BBD was absent. Moreover, we found no significant relationship between BBD prevalence and either the density or cover of corals in general or either scleractinian or acroporid corals specifically. One factor that may contribute to the absence of $\mathrm{BBD}$ from the majority of inshore reefs in this study is the higher turbidity and hence reduced light that is characteristic of inner-shelf reef environments. Antonius (1985a) found that sediment trapped amongst algae on newly exposed areas of coral skeleton prevented BBD development through suppression of photosynthesis by the cyanobacteria in low light environments. Consequently, turbid inshore environments may protect corals from infection by BBD by reducing the activity of the cyanobacteria. However, it is likely that prevalence of BBD is driven by a complex array of factors involving both host and pathogen characters, environmental parameters and coral community attributes.

Globally, there is concern that marine diseases are increasing in distribution and prevalence (Harvell et 
al. 1999), and 5 marine taxa have been identified as particularly at risk, including the scleractinian corals (Ward \& Lafferty 2004). While there is evidence of increasing prevalence (Weil 2004) and distribution (Porter et al. 2001) of coral disease in the Caribbean, lack of baseline data on the GBR obviates detection of trends in disease incidence in this reef region. Two studies suggest that the prevalence of coral disease on the GBR may have increased in recent years (Antonius \& Lipscomb 2001, Willis et al. 2004). Antonius \& Lipscomb (2001) found that the number of cases of SEB increased from rare (1 to 3 cases/30 min swim) to moderate (4 to 12 cases per 30 min swim) between 1988 and 1998 at Lizard Island in the northern sector examined in this study. Willis et al. (2004) also showed that the distribution and number of cases of white syndrome (WS) increased (20-fold for WS abundance) between 1998 and 2003. In both studies the relationship between the abundance of disease cases and disease prevalence is unclear without concurrent data on the number of healthy corals. In contrast to the detected increase in disease cases, the prevalence of BBD appears to have declined at sheltered sites at the northern sector over the last decade, from $2.8 \%$ of all corals in 1994 (Dinsdale 2000) to $1.7 \%$ in 2003 (Willis et al. 2004) and $0.095 \%$ in 2004 (this study). At 2 other reefs, BBD prevalence has remained low and stable: at No Name Reef, an outer-shelf reef in the northern sector, BBD prevalence was $0.051 \%$ in 2003 (Willis et al. 2004) compared to $0 \%$ in 2004 (this study); and at Heron Island in the southern sector, prevalence was $0.01 \%$ in 2003 (Willis et al. 2004) compared to $0.012 \%$ in 2004 (this study). These values span a range similar to that recorded for BBD prevalence in the wider Caribbean (0.2 to $6.0 \%$, reviewed in Weil 2004). Having established baseline levels of BBD prevalence for reefs spanning $2 / 3$ of the length of the GBR, it will now be possible to detect temporal trends in BBD prevalence and compare its ecological impacts on GBR coral assemblages with those in other reef regions.

This study expands the host range of corals susceptible to BBD on the GBR to 40 species from the 32 previously recorded (Willis et al. 2004). Inclusion of species in the genera Echinopora, Seriatopora, Psammocora and Cyphastrea (Willis et al. 2004, this study) increases the number of Indo-Pacific genera known to be susceptible to BBD from 17 (Sutherland et al. 2004) to 21. Our study also contributes a further 12 species to the list of 45 coral species known to be susceptible to BBD in the Indo-Pacific compiled by Sutherland et al. (2004). Increases in the number of taxa susceptible to BBD are expected to increase as coral disease surveys are completed in previously unsurveyed areas of the Pacific in particular. While BBD affected a wide variety of scleractinian families in our surveys, the family
Acroporidae was by far the most susceptible, accounting for $90 \%$ of records. Previous authors reported Pocilloporidae as the family most susceptible to BBD on the GBR, followed by the Acroporidae (Dinsdale 2000, Willis et al. 2004). However, our different results reflect the inclusion of a greater number of reefs from all cross-shelf positions in our survey and a concomitant reduction in the relative proportion of corals sampled in the Pocilloporidae because of their lower abundance on inner-shelf reefs. Willis et al. (2004) proposed that investment in rapid growth and reproduction by both the Acroporidae and Pocilloporidae may result in less well developed resistance to disease. Although acroporid corals are relatively resistant to infection by BBD compared to faviid corals in the Caribbean, they are the most susceptible to infection by other diseases such as white band (Gladfelter 1982) and white pox (Patterson et al. 2002) in this region. The relationship between life history characteristics and susceptibility to coral disease in general or to specific coral diseases remains unclear but is worthy of more detailed analysis given the potential impact of coral disease on coral diversity worldwide.

BBD has been known to develop on corals previously affected by white plague, white plague-like disease or WS (Antonius 1981a,b, 1985a,b) (see Willis et al. 2004) for discussion of the use of the term 'white syndrome' for Indo-Pacific corals), while SEB has been found to develop on corals previously affected by white plague (Antonius \& Lipscomb 2001). However, cases of corals affected by 2 diseases simultaneously have not previously been reported. Of the BBD cases recorded in this study, $10.3 \%$ were from colonies showing signs of other disease states, particularly SEB, bleaching or both SEB and bleaching simultaneously, or were of compromised health (Table 3). It is possible that corals infected with BBD are more vulnerable to invasion by other pathogens at sites of tissue necrosis along the disease front. Conversely, it is also possible that initial BBD infections may be dependant on a previous injury (Antonius 1981a,b, 1985a,b), infection with another disease (Antonius 1977, 1981b, Winkler et al. 2004) or compromised colony health. It is not possible to distinguish whether the co-occurrence of BBD and bleaching suggests that bleaching plays a role in the initiation or progress of BBD infection or vice versa. Halofolliculina corallasia ciliates have not previously been described in association with BBD or any other coral disease, despite the common occurrence of these ciliates amongst BBD infections on the GBR (associated with $6 \%$ of $\mathrm{BBD}$ infections). The co-occurrence of $H$. corallasia amongst the BBD mat makes it difficult to determine the relative contribution of each pathogen to the recent coral mortality and it is also unclear 
how the presence of one influences the progression or activity of the other pathogen.

A number of cyanobacterial infections that differed in colour and morphology from the typical black mat of BBD were recorded during this study and also by Willis et al. (2004). In many of these cases, the cyanobacteria formed only a thin line at the interface between live coral tissue and recently denuded skeleton. Given the low abundance of cyanobacteria in these bands, monitoring of tagged infected colonies is required to determine whether they are the primary cause of the recent coral mortality or if they opportunistically settle at the interface following injury or predation. After black, the most common colouration of cyanobacteria was green, followed by brown or red. In one case, red cyanobacteria formed a distinct red band $\sim 5 \mathrm{~cm}$ wide (cf. Richardson 1992). Sussman et al. (this issue) discuss cyanobacterial strains identified in a similar red band observed in Palau. Further studies of cyanobacterial infections of corals are required to determine how many strains are involved and whether they can be distinguished using gross morphological characteristics in the field.

\section{CONCLUSIONS}

BBD is widely distributed on the GBR, being recorded from the northern, central and southern sectors and from outer-, mid- and some inner-shelf reefs. Patterns of highest BBD prevalence in the comparatively pristine northern sector, and on mid-shelf reefs in cross-shelf transects, suggest that BBD distribution on the GBR is not linked to gradients in terrestrial influences, at least when overall BBD prevalence is low $(0.9 \% \pm 0.04)$. We speculate that the absence of BBD on $80 \%$ of inshore reefs suggests that high turbidity and sedimentation adversely affect cyanobacteria and protect corals from BBD infections. BBD has a wide host range on the GBR, infecting corals in 7 scleractinian families and one soft coral family; however, branching species of Acropora in the family Acroporidae are the most common hosts. Long-term, largescale studies of coral disease are required to establish spatial and temporal trends in coral disease prevalence and allow more accurate risk assessment of the potential impact of BBD and other coral diseases on coral communities of the GBR.

Acknowledgements. We thank S. Neale, D. Thompson, D. Bourne, S. Anthony, M. Sussman and the crew of the RV 'Lady Basten' for assistance in the field; and L. Vail, A. Hoggett and L. Pearce at Lizard Island Research Station, P. Venables at Orpheus Island Research Station and staff at Heron Island for logistical support. We also thank P. Munday and C. Syms for statistical advice and S. Kininmonth for Fig. 1.
This research was supported by the Australian Institute of Marine Science, and was funded by James Cook University, a Great Barrier Reef Science for Management Award, the 2004 Lizard Island Fellowship awarded to C.P. grants from the World Bank/Global Environment Facility and an Australian Research Council Discovery Grant awarded to B.W.

\section{LITERATURE CITED}

Al-Moghrabi SM (2001) Unusual black-band disease (BBD) outbreak in the northern tip of the Gulf of Aqaba (Jordan). Coral Reefs 19:330-331

Antonius A (1973) New observations of coral destruction in reefs. Assoc Isl Mar Lab Caribb, Mayaguez 10:3

Antonius A (1977) Coral mortality in reefs: a problem for science and management. Proc 3rd Int Coral Reef Symp, Miami 2:618-623

Antonius A (1981a) The 'band' diseases in coral reefs. Proc 4th Int Coral Reef Symp, Manila 2:7-14

Antonius A (1981b) Coral reef pathobiology: a review. Proc 4th Int Coral Reef Symp, Manila 2:3-6

Antonius A (1985a) Black band disease infection experiments on hexacorals and octocorals. Proc 5th Int Coral Reef Congr, Moorea 6:155-160

Antonius A (1985b) Coral disease in the Indo-Pacific: a first recording. PSZN I: Mar Ecol 6:197-218

Antonius A (1988) Distribution and dynamics of coral diseases in the eastern Red Sea. Proc 6th Int Coral Reef Symp, Townsville 2:293-298

Antonius A, Lipscomb D (2001) First protozoan coral-killer identified in the Indo-Pacific. Atoll Res Bull 481-493:1-21

Bruckner A, Bruckner R (1997) The persistence of black-band disease in Jamaica: impact on community structure. Proc 8th Int Coral Reef Symp, Panama 1:601-606

Bruckner AW, Bruckner JRJ, Williams EH Jr (1997) Spread of a black-band disease epizootic though the coral reef system in St. Ann's Bay, Jamaica. Bull Mar Sci 61:919-928

Bruno JF, Petes LE, Harvell CD, Hettinger A (2003) Nutrient enrichment can increase the severity of coral disease. Ecol Lett 6:1056-1061

Cheal AJ, Coleman G, Delean S, Fitzpatrick B, Miller I, Osborne K, Page CA, Sweatman H (2001) Status of fringing reefs and options for long-term monitoring in the Northumberland Islands, southern Great Barrier Reef, Australia. Report no. 33, Aust Inst Mar Sci

Dinsdale EA (2000) Abundance of black-band disease on corals from one location on the Great Barrier Reef: a comparison with abundance in the Caribbean region. Proc 9th Int Coral Reef Symp, Bali 2:1239-1243

Done TJ (1982) Patterns in the distribution of coral communities across the Central Great Barrier Reef. Coral Reefs 1:95-107

Edmunds P (1991) Extent and effect of black-band disease on a Caribbean reef. Coral Reefs 10:161-165

Frias-Lopez J, Zerkle AL, Bonheyo GT, Fouke BW (2002) Partitioning of bacterial communities between seawater and healthy, black-band diseased, and dead coral surfaces. Appl Environ Microbiol 68:2214-2228

Frias-Lopez J, Bonheyo GT, Jin Q, Fouke BW (2003) Cyanobacterial diversity associated with coral black band disease in Caribbean and Indo-Pacific Reefs. Appl Environ Microbiol 69:2409-2413

Furnas M (1991) The nutrient status of Great Barrier Reef waters. In: Yellowlees D (ed) Land use patterns and nutrient loading of the Great Barrier Reef. James Cook University, Townsville 
Furnas M (2003) Catchment and corals: terrestrial runoff to the Great Barrier Reef. Aust Inst Mar Sci, Townsville

Furnas MJ, Mitchell AW, Liston P, Skuza M, Drew E, Wellington J (1990) Biological and chemical oceanographic measurements in the far northern Great Barrier Reef. Research Publication No. 34, Great Barrier Reef Marine Park Authority, Townsville

Garrett P, Ducklow H (1975) Coral disease in Bermuda. Nature 253:349-350

Gladfelter WB (1982) White-band disease in Acropora palmata: implications for the structure and growth of shallow reefs. Bull Mar Sci 32:639-643

Harvell CD, Kim K, Burkholder J, Colwell RR and 9 others (1999) Emerging marine diseases-climate links and anthropogenic factors. Science 285:1505-1510

Harvell CD, Aronson R, Baron N, Connell J and 13 others (2004) The rising tide of ocean diseases: unsolved problems and research priorities. Front Ecol Environ 2:275-382

Kuta KG, Richardson LL (1996) Abundance and distribution of black band disease on coral reefs in the northern Florida Keys. Coral Reefs 15:219-223

Kuta KG, Richardson LL (2002) Ecological aspects of black band disease of corals: relationships between disease incidence and environmental factors. Coral Reefs 21:393-398

Littler M, Littler D (1996) Black-band disease in the South Pacific. Coral Reefs 15:20

McCullagh P, Nelder JA (1989) Generalized linear models, 2nd edn. Chapman \& Hall, London

Miller I (1996) Black-band disease on the Great Barrier Reef. Coral Reefs 15:58

Ninio R, Meekan MG (2002) Spatial patterns in benthic communities and the dynamics of a mosaic ecosystem on the Great Barrier Reef, Australia. Coral Reefs 21:95-103

Patterson KL, Porter JW, Ritchie KB, Polson SW, Mueller E, Peters EC, Santavy DL, Smith GW (2002) The etiology of white pox, a lethal disease of the Caribbean elkhorn coral, Acropora palmata. Proc Natl Acad Sci USA 99:8725-8730

Porter J, Dustan P, Jaap W, Patterson KL, Kosmynin V, Meier O, Patterson M, Parsons M (2001) Patterns of spread of coral disease in the Florida Keys. Hydrobiologia 460:1-24

Submitted: September 28, 2004; Accepted: November 7, 2005
Raymundo LJ, Rosell KB, Reboton CT, Kaczmarsky L (2005) Coral disease on Philippine reefs: genus Porites is a dominant host. Dis Aquat Org 64:181-191

Richardson LL (1992) Red band disease: a new cyanobacterial infestation of corals. In: Cahoon LB (ed) Proc 10th Am Acad Underw, Wilmington, p 153-160

Rutzler K, Santavy DL, Antonius A (1983) The black band disease of Atlantic reef corals. III. Distribution, ecology and development. PSZN I: Mar Ecol 4:329-358

Santavy D, Mueller E, Peters E, MacLaughlin L, Porter J, Patterson K, Campbell J (2001) Quantitative assessment of coral diseases in the Florida Keys: strategy and methodology. Hydrobiologia 460:39-52

Sutherland KP, Porter JW, Torres C (2004) Disease and immunity in Caribbean and Indo-Pacific zooxanthellate corals. Mar Ecol Prog Ser 266:273-302

Sweatman H, Cheal A, Coleman G, Delean S and 6 others (2001) Long-term monitoring of the Great Barrier Reef. Status Report No. 5, Aust Inst Mar Sci, Townsville

Taylor D (1983) The black-band disease of Atlantic reef corals. II. Isolation, cultivation, and growth of Phormidium corallyticum. PSZN I: Mar Ecol 4:320-328

Ward JR, Lafferty KD (2004) The elusive baseline of marine disease: are diseases in ocean ecosystems increasing? PLOS Biol 2:542-547

Weil E (2004) Coral reef disease in the wider Caribbean: status and prognosis. In: Rosenberg E, Loya Y (eds) Coral disease and Heath. Springer, Berlin, p 35-64

Weil E, Urreiztieta I, Garzón-Ferreira J (2002) Geographic variability in the incidence of coral and octocoral disease in the wider Caribbean. Proc 9th Int Coral Reef Symp, Bali, p 1231-1237

Willis BL, Page CA, Dinsdale EA (2004) Coral disease on the Great Barrier Reef. In: Rosenberg E, Loya Y (eds) Coral disease and health. Springer, Berlin, p 69-104

Winkler R, Antonius A, Abigail Renegar D (2004) The skeleton eroding band disease on coral reefs of Aqaba, Red Sea. PSZN I: Mar Ecol 25:129-144

Wolanski E, Richmond R, McCook L, Sweatman H (2003) Mud, marine snow and coral reefs. Am Sci 91:44-51

Proofs received from author(s): February 24, 2006 